\title{
A PÁLINKAKÉSZÍTÉS TALAJVÉDELMI KIHÍVÁSAI
}

\author{
Barczi Attila - Nagy Valéria
}

\begin{abstract}
Absztrakt: A pálinka Magyarországon a Hungarikum Bizottság döntése értelmében 2013. márciusa óta hungarikumnak minősül. A pálinkakészítés (erjesztés és lepárlás) melléktermékeként 1 hlf alkohol elöállítása során $-27,5$ liter cefremoslék (kierjesztési és lepárlási maradék) keletkezik, amelynek beltartalmi tulajdonságai lehetővé teszik a további - mezőgazdasági célú - hasznosítását, bizonyos feltételekkel tehát a termőföldre történö kihelyezés is megvalósítható. Kémiai tulajdonságait tekintve a cefremoslék erősen savas kémhatású, jelentős $K$ és $P$ tartalommal bír, továbbá a lepárlási technológiából eredően elöfordulhat fémtartalom is, amely korlátozó tényező lehet a termőföldi hasznosításnál. Laboratóriumi vizsgálatok, valamint helyszíni talajvizsgálatok segítségével meghatározható az a kihelyezhető mennyiség, amely környezet- és talajvédelmi szempontból nem jelent kockázatot, ugyanakkor a növénytáplálást is szolgálja. A termöföldre történő kihelyezés korlátai a pálinkakészítés melléktermékének tekintetében tehát a cefremoslék beltartalmi mutatói, azonban problémát jelent még a késő őszi és téli tilalmi idöszak, amikor pálinkakészítés még zajlik, de a cefremoslék a fagyott talajra már nem helyezhetö ki.
\end{abstract}

Abstract: According to the decision of the Hungarikum Committee, the 'Pálinka' has been considered Hungarikum since March 2013. During the 'Pálinka' production (fermentation and distillation) "fermentation and distillation residue" (the solids from the alcohol production and the liquids left over from the distillation) is produced as by-product. Its nutritional properties allow for further agricultural utilization. Under certain circumstances, therefore, it can be used on arable lands. In terms of its properties, the "fermentation and distillation residue" has acidic $\mathrm{pH}$ and significant content of $\mathrm{K}$ and $\mathrm{P}$, furthermore metal content may also occur because of the distillation technology, and it can be a limiting factor in case of arable land utilization. With the help of laboratory test and on-site soil analyze can be determined the quantity which does not risk for environmental and soil protection, but also serves of plant nutrition. The limitations in arable land utilization for the byproduction of 'Pálinka' are parameters of "fermentation and distillation residue", however, there is a problem in the late autumn and winter prohibition period when the 'Pálinka' production is still going on, but the "fermentation and distillation residue" can no longer be taken on the frozen soil.

Kulcsszavak: pálinkakészítés, melléktermék, termőföld, talajvizsgálatok

Keywords: 'Pálinka' production, by-product, arable land, soil tests

\section{Bevezetés}

A pálinkáról, a törkölypálinkáról és a Pálinka Nemzeti Tanácsról alkotott 2008. évi LXXIII. törvény 2. § (1) értelmében pálinkának csak a többször módosított és helyesbített 110/2008/EK rendelet II. számú mellékletének 9. számú kategóriája szerinti eljárással készített olyan gyümölcspárlat nevezhető, amelyet Magyarországon termett gyümölcsből - ideértve a gyümölcsvelöt is - készítettek, és amelynek cefrézését, párlását, érlelését és palackozását is Magyarországon végezték. (Itt megjegyzendő, hogy sürítményből, aszalványból, szárítmányból készült termék nem nevezhető pálinkának.)

A pálinkát nem lehet ízesíteni, színezni, édesíteni még a termék végső ízének lekerekítése érdekében sem (HTTP1). 
Magyarország kormánya a magyar nemzeti értékek és a hungarikumok gondozásáról szóló 114/2013. (IV. 16.) Korm. rendelettel szabályozza a Magyar Értéktárban nyilvántartott valamely nemzeti érték hungarikummá minősítésének folyamatát.

A magyar nemzeti értékekröl és a hungarikumokról hozott 2012. évi XXX. törvényben az Országgyülés Magyarország Alaptörvényének $P$ ) cikke alapján a magyar nemzet egységétől vezérelve megállapítja, hogy a magyar nemzeti értékek, köztük a hungarikumok megörzendő és egyedülálló értékek. E törvény alkalmazásában a hungarikum gyüjtőfogalom, egységes osztályozási, besorolási és nyilvántartási rendszerben olyan megkülönböztetésre, kiemelésre méltó értéket jelöl, amely a magyarságra jellemző tulajdonságával, egyediségével, különlegességével és minöségével a magyarság csúcsteljesítménye.

\section{A pálinkakészités folyamata}

A pálinka előállítása többlépcsős folyamat. A teljes folyamat lényege és célja, hogy a pálinkába minél többet mentsünk át a gyümölcs értékeiböl, illatából, ízéből, frissességéből, jellegzetes aromavilágából. A pálinka tehát a gyümölcs lelke, íz- és illatvilágának esszenciája. A pálinkakészítés teljes folyamatát ezért ennek a szemléletnek és elkötelezettségnek kell jellemeznie (sólyom, 1986; HTTP2; HTTP3).

\section{A pálinkakészítés szakaszai:}

1. Gyümölcsök elökészítése

Pálinka készítéséhez csak kifogástalan minőségü, érett gyümölcs (cukortartalom és aromatartalom) használható fel. A csonthéjasokat ki kell magozni (annak érdekében, hogy a magban lévő ciántartalom ne kerüljön a cefrébe), az almaféléket pedig le kell darálni.

\section{Cefrézés, a cefre erjesztése}

Az elökészített gyümölcsöt, a cefrét erjesztik (hozzáadott cukor nélkül). Az erjesztés során a gyümölcs cukortartalma élesztők közremüködésével alkohollá alakul, illetve az elsődleges aromaalkotók felszabadulnak és létrejönnek a másodlagos aromakomponensek. Ezek együttesen átkerülve a pálinkába, annak egyedi karakterét adják majd. Az erjedési folyamat meggyorsítása, illetve annak minél teljesebb körü végbemenetele érdekében felhasználható és megengedett segédanyagok a következők: enzimek, savak, élesztők, derítőszerek, a nehézfémek eltávolítására alkalmas segédanyagok, habzásgátló, tápsó.

Fontos, hogy a cefre levegötől elzártan (anaerob) körülmények között erjedjen. A cefre erjedése során hő szabadul fel (optimális erjedési hőmérséklete $17-18^{\circ} \mathrm{C}$, a túlmelegedésnek a végtermék ízére (is) negatív hatása van). Az erjesztés időtartama (a gyümölcstől és a körülményektől függően) 2-3 hét.

\section{Lepárlás, a ,pálinkafözés"}

A lepárlás során a cefre egyes alkotóelemeit (melyeknek különböző az illékonysága) desztillációval választják szét. Ezt az egyszerú szétválasztási elvet alkalmazzák a pálinkafőző berendezések. Maga a lepárlás folyamata kétfajta módon, kétfajta eljárással történhet: 
„Kisüsti”, kétszeri szakaszos lepárlással (két különálló desztilláció során kapunk készterméket), amelynek első fázisában felmelegítik a cefrét és desztillációval kinyerik belöle az etil-alkoholt és az egyéb illó anyagokat. Az így kapott alkoholos folyadék az alszesz, amelyet egy második fázisban tovább finomítanak. Ekkor választják el a középpárlattól - amely tulajdonképpen a pálinka - a nem megfelelö íz- és illatanyagokat tartalmazó elö- és utópárlatot.

A kisüsti elnevezés onnan származik, hogy a lepárló berendezés ürtartalma maximum ezer liter lehet.

A másik módszer a „Tornyos” eljárás, egyszeri lepárlással. E technológia esetében a cefre „fözését” és a finomítást egy lépésben végzik el. Az ilyen berendezésben a fözőüstöt egy aroma- és alkoholkoncentráló oszloppal kombinálják, ahol a cefre gőzzé alakítása után végbemegy a finomítás.

Mind a két fözési eljárásnál az a legfontosabb, hogy a fözési folyamat során időben elörehaladva keletkező cseppfolyósított anyag három részének - elö-, középés utópárlat - az elválasztása pontosan történjen meg. Ennek az elválasztásn,ak a lényege a középpárlat, a pálinka tökéletes szeparálása.

\section{Nemesítés (alkoholfok beállítása, pihentetés), palackozás}

A friss pálinka fogyasztásra még nem alkalmas, szeszfoka túl magas, „darabos”, ízei még nem harmonikusak. Ennek okán szükséges a pálinka - fogyasztásra alkalmas - alkohol koncentrációjának a beállítása (általában 40-60 (V/V)\%), de a gyümölcspárlat alkoholtartalma min. 37,5 (V/V)\%), amelyet lágy víz hozzáadásával érnek el. A pálinka harmóniáját ezt követően pihentetéssel hozzák létre, melynek időtartama általában 30-60 nap, ennek során a pálinka „megnyugszik”, belső egyensúlya rendeződik, nyersessége megszünik; letisztul és lekerekedik, simábbá, jobban ihatóvá válik (Sólyom, 1986; HTTP2; HTTP3).

Mivel a folyamat során 100 liter alapanyagból $\sim 5-10 \% \quad 50$ (V/V)\% alkoholtartalmú párlat nyerhető, felvetődik a kérdés, hogy a pálinkakészítés (erjesztés és lepárlás) melléktermékeként visszamaradó savas kémhatású cefremoslék (kierjesztési és lepárlási maradék) mezőgazdasági célú (termőföldre történő kihelyezés) hasznosítása milyen módon, milyen peremfeltételekkel valósítható meg.

\section{A cefremoslék mezőgazdasági célú hasznosítása}

A termőföldön felhasználható melléktermékek és hulladékok egy része a talajvédelmi szempontok érvényesítése érdekében csak bizonyos feltételekkel helyezhető ki. Ennek jogszabályi hátterét a szakmai alapokon nyugvó 90/2008. (VII. 18.) FVM rendelet adja. A cefremoslék, mint „nem mezőgazdasági eredetü nem veszélyes hulladék" e rendeletben a termőföldre történő kihelyezhetöség szempontjából nincs önállóan nevesítve. Ilyen módon a rendelet a nem nevesített anyagok (pl. biogáz üzemi fermentálási maradék, cefremoslék, kifözött (szőlő)törköly, fejöházi/konzervgyári mosóvíz stb.) minősítését a talajtani szakértők hatáskörébe utalta.

2013. augusztusától a talajvédelmi hatóság állásfoglalása alapján a termőföldre történő kihelyezés körülményeit rögzítő talajvédelmi terv készítésekor a nem 
mezőgazdasági eredetü nem veszélyes hulladékokra vonatkozó szabályokat kell alkalmazni a következö kiegészítésekkel:

- A cefremoslék mintából - mint a talajra kihelyezendö anyagból - a következő paramétereket kell csak vizsgálni: pH, vízoldható összes só, összes szárazanyag, összes szervesanyag, összes $\mathrm{N}$, összes $\mathrm{P}\left(\mathrm{P}_{2} \mathrm{O}_{5}\right)$, összes $\mathrm{K}\left(\mathrm{K}_{2} \mathrm{O}\right), \mathrm{Cu}, \mathrm{Ca}, \mathrm{Na}, \mathrm{B}$. (Itt megjegyzendő azonban, hogy a $\mathrm{Cu}$ és $\mathrm{B}$ tápanyagként veendỏ figyelembe.)

- Talajvizsgálat esetében cefremoslék kihelyezésnél a hígtrágyára vonatkozó vizsgálati paramétereket kell előírni.

- Közegészségügyi védőtávolságokat és közegészségügyi várakozási időket nem kell elöírni.

A pálinkakészítés melléktermékének talajvédelmi szempontú értékeléséhez több hazai pálinkafözde többféle alapanyagából származó cefremoslék átlagmintáinak akkreditált laboratóriumi vizsgálata alapján kiállított vizsgálati jegyzőkönyveket használjuk. A vizsgálati jegyzőkönyvekben rögzített paraméterek értékeit táblázatos formában összesítve történik a kiértékelés.

\section{Eredmények és értékelésük}

$\mathrm{Az}$ 1. táblázat több jegyzőkönyv adatait összefoglalva tartalmazza a tápanyaggazdálkodási, illetve talajvédelmi szempontból általunk kiválasztott paramétereket.

\section{1. táblázat: Cefremoslék talajvédelmi jelentőségü paraméterei}

\begin{tabular}{|c|c|c|c|c|c|c|c|c|}
\hline & $\begin{array}{c}\mathbf{p H} \\
{[-]}\end{array}$ & $\begin{array}{c}\text { összes } \\
\text { oldott só }\end{array}$ & $\mathbf{N a}$ & $\begin{array}{l}\text { összes N } \\
\text { (Kjeldahl) }\end{array}$ & $\mathbf{P}$ & $\mathbf{K}$ & $\mathbf{B}$ & $\mathrm{Cu}$ \\
\hline minta1 & 3,51 & $\begin{array}{c}31000 \\
\mathrm{mg} / \mathrm{l}\end{array}$ & $\begin{array}{l}39,6 \\
\mathrm{mg} / \mathrm{l} \\
\end{array}$ & $\begin{array}{c}373 \\
\mathrm{mg} / 1\end{array}$ & $\begin{array}{c}151 \\
\mathrm{mg} / 1\end{array}$ & $\begin{array}{l}1721 \\
\mathrm{mg} / 1\end{array}$ & $\begin{array}{l}2,35 \\
\mathrm{mg} / 1\end{array}$ & $\begin{array}{l}3,06 \\
\mathrm{mg} / 1\end{array}$ \\
\hline minta2 & 3,33 & $\begin{array}{c}27500 \\
\mathrm{mg} / \mathrm{dm}^{3}\end{array}$ & $\begin{array}{c}28,5 \\
\mathrm{mg} / \mathrm{dm}^{3}\end{array}$ & $\begin{array}{c}546 \\
\mathrm{mg} / \mathrm{dm}^{3}\end{array}$ & $\begin{array}{c}694 \\
\mathrm{mg} / \mathrm{dm}^{3}\end{array}$ & $\begin{array}{c}1800 \\
\mathrm{mg} / \mathrm{dm}^{3}\end{array}$ & $\begin{array}{c}3,93 \\
\mathrm{mg} / \mathrm{dm}^{3}\end{array}$ & $\begin{array}{c}4,11 \\
\mathrm{mg} / \mathrm{dm}^{3}\end{array}$ \\
\hline minta3 & 3,66 & $\begin{array}{c}61100 \\
\mathrm{mg} / \mathrm{dm}^{3}\end{array}$ & $\begin{array}{c}35,7 \\
\mathrm{mg}^{2} \mathrm{dm}^{3}\end{array}$ & $\begin{array}{c}1197 \\
\mathrm{mg} / \mathrm{dm}^{3}\end{array}$ & $\begin{array}{c}321 \\
\mathrm{mg} / \mathrm{dm}^{3}\end{array}$ & $\begin{array}{c}2497 \\
\mathrm{mg} / \mathrm{dm}^{3}\end{array}$ & $\begin{array}{c}4,27 \\
\mathrm{mg} / \mathrm{dm}^{3}\end{array}$ & $\begin{array}{c}4,98 \\
\mathrm{mg} / \mathrm{dm}^{3}\end{array}$ \\
\hline minta4 & 3,64 & $\begin{array}{c}73100 \\
\mathrm{mg} / \mathrm{dm}^{3} \\
\end{array}$ & $\begin{array}{c}23,7 \\
\mathrm{mg} / \mathrm{dm}^{3} \\
\end{array}$ & $\begin{array}{c}1080 \\
\mathrm{mg} / \mathrm{dm}^{3}\end{array}$ & $\begin{array}{c}244 \\
\mathrm{mg} / \mathrm{dm}^{3} \\
\end{array}$ & $\begin{array}{c}2530 \\
\mathrm{mg} / \mathrm{dm}^{3} \\
\end{array}$ & $\begin{array}{c}5,21 \\
\mathrm{mg}^{2} \mathrm{dm}^{3} \\
\end{array}$ & $\begin{array}{c}6,77 \\
\mathrm{mg} / \mathrm{dm}^{3} \\
\end{array}$ \\
\hline minta5 & 3,82 & $\begin{array}{c}23500 \\
\mathrm{mg} / \mathrm{dm}^{3}\end{array}$ & $\begin{array}{c}24,3 \\
\mathrm{mg} / \mathrm{dm}^{3}\end{array}$ & $\begin{array}{c}771 \\
\mathrm{mg} / \mathrm{dm}^{3}\end{array}$ & $\begin{array}{c}254 \\
\mathrm{mg} / \mathrm{dm}^{3}\end{array}$ & $\begin{array}{c}1600 \\
\mathrm{mg} / \mathrm{dm}^{3}\end{array}$ & $\begin{array}{c}2,91 \\
\mathrm{mg}^{2} / \mathrm{dm}^{3}\end{array}$ & $\begin{array}{c}4,71 \\
\mathrm{mg} / \mathrm{dm}^{3}\end{array}$ \\
\hline minta6 & 3,39 & $\begin{array}{c}20700 \\
\mathrm{mg} / \mathrm{l}\end{array}$ & $\begin{array}{l}8,38 \\
\mathrm{mg} / 1 \\
\end{array}$ & $\begin{array}{c}454 \\
\mathrm{mg} / \mathrm{l}\end{array}$ & $\begin{array}{r}140 \\
\mathrm{mg} / \mathrm{l}\end{array}$ & $\begin{array}{l}1300 \\
\mathrm{mg} / \mathrm{l}\end{array}$ & $\begin{array}{l}2,88 \\
\mathrm{mg} / 1 \\
\end{array}$ & $\begin{array}{l}6,29 . \\
\mathrm{mg} / 1\end{array}$ \\
\hline minta 7 & 3,80 & $\begin{array}{c}21500 \\
\mathrm{mg} / 1\end{array}$ & $\begin{array}{l}11,2 \\
\mathrm{mg} / 1\end{array}$ & $\begin{array}{l}404 \\
\mathrm{mg} / 1\end{array}$ & $\begin{array}{c}121 \\
\mathrm{mg} / 1\end{array}$ & $\begin{array}{l}1089 \\
\mathrm{mg} / 1\end{array}$ & $\begin{array}{l}4,64 \\
\mathrm{mg} / 1\end{array}$ & $\begin{array}{l}4,09 \\
\mathrm{mg} / 1\end{array}$ \\
\hline minta8 & 3,91 & $\begin{array}{c}18100 \\
\mathrm{mg} / \mathrm{l}\end{array}$ & $\begin{array}{c}28 \\
\mathrm{mg} / 1\end{array}$ & $\begin{array}{r}391 \\
\mathrm{mg} / \mathrm{l}\end{array}$ & $\begin{array}{l}265 \\
\mathrm{mg} / \mathrm{l}\end{array}$ & $\begin{array}{l}1373 \\
\mathrm{mg} / 1\end{array}$ & $\begin{array}{c}3,4 \\
\mathrm{mg} / 1\end{array}$ & $\begin{array}{c}5,0 \\
\mathrm{mg} / \mathrm{l}\end{array}$ \\
\hline
\end{tabular}

Forrás: A szerzök saját szerkesztése.

A cefrézés során, illetve az alkoholos erjesztés folyamata alatt erősen savas karakterü anyag keletkezik. A cefre „kifözését” követően a pH érték nem változik jelentősen, ezért a kifőzött cefremoslék kémhatása az erősen savas tartományban 
marad. A termőföldre történő kihelyezésnél ez jelenti az egyik legfontosabb limitáló tényezöt. Míg semleges vagy gyengén lúgos, meszes talajokon a kihelyezett cefremoslék savanyító hatása lassan érvényesül, addig a savanyú talajokon további pH csökkenést idéz elö. Ezért ez utóbbi területeken (pl. dombságok, hegységek savas kémhatású erdőtalajain) a cefremoslék kihelyezése csak meszezés mellett lehetséges.

A vizsgálati jegyzökönyvek alapján a cefremoslék összes oldott sótartalma jelentős (18000-73000 mg/l). Mivel folyékony karakterü anyagról van szó, ezért a talajra történő kihelyezésnél számolni kell azzal, hogy a beszivárgó anyag egyrészt növeli a talaj sótartalmát, másrészt az $5 \mathrm{~m}$ terepszint alatti mélységig elhelyezkedő talajvízzel érintkezve annak sótartalmát jelentősen megnövelheti, és a talajvíz bepárlódása esetén másodlagos szikesedést okozhat. Ennek okán a kijuttatás dózisát és gyakoriságát úgy kell megtervezni, hogy a cefremoslék és a talajvíz ne kerülhessen kapcsolatba. A Na és B-tartalom szintén a szikesedés, sófelhalmozódás veszélye miatt lehet limitáló tényező.

A cefremoslék $\mathrm{N}, \mathrm{P}$ és $\mathrm{K}$ tartalma a növényi tápanyagellátásban játszanak szerepet, ezért tápanyag-gazdálkodási céllal tervezhető a kijuttatás. A kihelyezhető dózist a cefremoslék beltartalma, a kihelyező terület talajának tápanyagtartalma, valamint a termesztett növény tápanyagigénye együttesen szabják meg (FülekySárdi, 2014).

A ,minta1" vizsgálati eredményei alapján pl. $1 \mathrm{~m}^{3}$ cefremoslékkal $0,396 \mathrm{~kg} \mathrm{~N}$, $3,46 \mathrm{~kg} \mathrm{P}\left(\mathrm{P}_{2} \mathrm{O}_{5}\right.$ hatóanyagra átszámítva) és $20,73 \mathrm{~kg} \mathrm{~K}\left(\mathrm{~K}_{2} \mathrm{O}\right.$ hatóanyagra átszámítva) kerül kijuttatásra hektáronként. Amennyiben az elhelyező területek nem nitrátérzékenyek, évente max. $200 \mathrm{~kg} / \mathrm{ha}$ lehet a kijuttatható $\mathrm{N}$ hatóanyag mennyisége, nitrátérzékenység esetén pedig évente $170 \mathrm{~kg} / \mathrm{ha} \mathrm{N}$ hatóanyag kijuttatása lehetséges. A 90/2008. (VII. 18.) FVM rendelet alapján a kijuttatott K hatóanyag mennyisége nem lehet több, mint évi $250 \mathrm{~kg} / \mathrm{ha}$, a $\mathrm{P}$ hatóanyag mennyisége pedig évente $150 \mathrm{~kg} / \mathrm{ha}$. Tekintettel arra, hogy a termesztendö növények tápanyagigénye alapján kijuttatható cefremoslék dózis többnyire meghaladja a jogszabályi elöírások szerinti mennyiségét, az elhelyező területekre kihelyezhető cefremoslék éves mennyiségét nem a termesztett növénykultúra tápanyagigénye, hanem a fentebb említett, szakmai alapokon nyugvó jogszabályi elöírások határozzák meg. A felhasználható cefremoslék mennyiségének kiszámításakor a limitáló tényező a legtöbb esetben a $\mathrm{K}$ és/vagy a $\mathrm{P}$.

A pálinkakészítési technológiából adódóan, valamint a felhasznált gyümölcsök beltartalmi jellemzöitől függően a cefremoslékok $\mathrm{Cu}$ és $\mathrm{B}$ tartalma figyelemre méltó (az 1. táblázat mintáinak paraméterei alapján). A B nélkülözhetetlen növényi tápanyag, szerepe van a cukorképződésben, de a tápanyagszállítással kapcsolatban, valamint a virág- és termésképzésben is szerepet játszik. Ugyanakkor a B magas talajkoncentrációja $(1,8 \mathrm{mg} / \mathrm{kg}$ felett) esetén a növények bór-toxicitás tüneteit mutatják (Blevins, 1998). A Cu a talajokban $75 \mathrm{mg} / \mathrm{kg}$ felett már toxikusnak tekinthetö (50/2001. (IV. 3.) Korm. rendelet), ezért a kihelyezhető cefremoslék mennyiségét ez is korlátozhatja. Azonban a 2013-as talajvédelmi hatósági állásfoglalás szerint a $\mathrm{Cu}$ - és B-tartalmat esszenciális mikroelemként kell figyelembe 
venni, így amennyiben a növény igényeihez igazítjuk a kihelyezett $\mathrm{Cu}$ és $\mathrm{B}$ mennyiséget, úgy a talajokban szennyeződéssel nem kell számolni.

A kihelyezendő anyag vizsgálata mellett a talajállapot jellemzését is el kell végezni. A cefremoslék kihelyezéséhez ugyanis talajvédelmi tervet szükséges készíteni. A talajvédelmi terv célja a tervezett mezőgazdasági terület alkalmasságának (talaj, talajvíz, környezet) bemutatása, valamint a cefremoslék vizsgálati eredményeinek, illetve az adott területen termeszthető növények ismeretében az elméleti éves terhelhetőség kiszámítása. Ennek érdekében a tervezett kihelyező területen talajszelvényeket kell feltárni, amelyekböl genetikai szintenként történik a talajmintavétel, a terület talajtulajdonságainak és tápanyagtartalmának megállapítása érdekében pedig ún. átlagmintát is gyüjteni kell. Mintázandó továbbá a cefremoslék és az $5 \mathrm{~m}$ terepszint alatti mélységen belül elhelyezkedő talajvíz is. A mintavételek módját, valamint a vizsgálandó paraméterek körét és a vizsgálati módszerhez szükséges szabványokat a 90/2008. (VII. 18.) FVM rendelet tartalmazza. A laboratóriumi vizsgálatokat minden esetben akkreditált talajlaboratórium végezheti el.

Talajvédelmi terv, és az annak alapján kiadott szakhatósági engedélybirtokában a cefremoslék a talajra kihelyezhető, de a kihelyezés körülményeit úgy kell kialakítani, hogy az károsodást ne okozzon.

Azokban az időszakokban, amikor a talaj hóval borított, vízzel telített, fagyott, a cefremoslékot kihelyezni nem lehet, ekkor az anyagot ideiglenesen tárolni szükséges.

A kijuttatásnál különös figyelmet kell fordítani az egyenletességre, továbbá a terület helyi egyenetlenségeit, domborzati adottságait is szükséges figyelembe venni az esetleges összefolyások megakadályozása érdekében.

Tapasztalataink szerint a fenti előírások közül jelentősebb problémát a késő őszi és téli tilalmi időszak jelent, amikor a pálinkakészítés még zajlik, de a cefremoslék a talajra már nem helyezhető ki. E probléma egyik lehetséges megoldása pálinkafőző közösségenként az EU-s előírásoknak megfelelő, tervezett nagyságú, szigetelt tárolók létesítése.

A folyamatos kihelyezés hatására esetlegesen bekövetkező talajdegradációs folyamatok megakadályozása, illetve a változások nyomon követése érdekében éves rendszerességgel a termesztett növény igényeihez igazodó agrárhasznosítási terv készítése, valamint a talajvédelmi szakhatóság által elöírt, általában 5 évenként történő talajtani felülvizsgálat szükséges, amely során elsősorban a kémhatás, mésztartalom és tápanyagtartalom, egyes esetekben a mikroelem vizsgálatokra kell a hangsúlyt helyezni.

\section{Következtetések, összegzés, záró megjegyzések, záró gondolatok}

Közleményünk a fenntartható és alkalmazkodó mezőgazdálkodás interdiszciplináris jellegének kidomborításával kíván közvetetten hozzájárulni a felelős gazdaszemlélet kialakulásához. A cefremoslék talajra történő kihelyezésének lehetőségeit és korlátait mutattuk be. 
Környezet- és talajvédelmi szempontból a szerves hulladékok (újra)hasznosítása előnyös. A nem mezőgazdasági eredetü nem veszélyes melléktermékek, hulladékok mezőgazdasági célú hasznosítása elsősorban talajtani vizsgálatokra alapozottan történhet meg. Esetünkben a cefremoslék (kierjesztési és lepárlási maradék) erősen savas kémhatású, nem homogén anyag. A változó alapanyag szükségessé teszi, hogy változatlan technológia ellenére is évente meg kell határozni a cefremoslék beltartalmi jellemzőit amellett, hogy a talaj állapotának monitorozása érdekében talajfizikai- és talajkémiai alapvizsgálatok végzése is indokolt tápanyagtartalom meghatározással kiegészítetten.

Az egyéb, nem mezögazdasági célú hasznosítási lehetőségek megteremtéséhez, a hasznosítási mód megválasztásához, a felhasználással kapcsolatos döntések meghozatalához, valamint kidolgozott technológiák bevezetéséhez és azok alkalmazásához a jövőben fejlesztésorientált kutatások végzése indokolt.

\section{Irodalomjegyzék}

110/2008/EK rendelet a szeszes italok meghatározásáról, megnevezéséről, kiszereléséről, címkézéséről és földrajzi árujelzőinek oltalmáról.

114/2013. (IV. 16.) Korm. rendelet a magyar nemzeti értékek és a hungarikumok gondozásáról. 2008. évi LXXIII. törvény a pálinkáról, a törkölypálinkáról és a Pálinka Nemzeti Tanácsról.

2012. évi XXX. törvény a magyar nemzeti értékekröl és a hungarikumokról.

50/2001. (IV. 3.) Korm. rendelet a szennyvizek és szennyviziszapok mezőgazdasági felhasználásának és kezelésének szabályairól.

90/2008. (VII. 18.) FVM rendelet a talajvédelmi terv készítésének részletes szabályairól

Blevins, D. G. (1998): Functions of Boron in Plant Nutrition. Annual Review of Plant Physiology and Plant Molecular Biology, 49: 481-500.

Füleky Gy., Sárdi K. (2014): Tápanyag-gazdálkodás mezőgazdasági mérnököknek. Mezögazda Kiadó, Budapest.

Sólyom L. (1986): Pálinkakészítés - kézikönyv kisüzemek számára. Mezögazda Kiadó, Budapest.

HTTP1: <http://www.hungarikum.hu/hu/p\%C3\%A1linka> (2017.09.11.)

HTTP2: 〈http://www.palinka.com/hu/palinka/palinka-eloallitasa/> (2017.09.11.)

HTTP3: 〈https://hu.wikipedia.org/wiki/P\%C3\%A1linka> (2017.09.11.) 